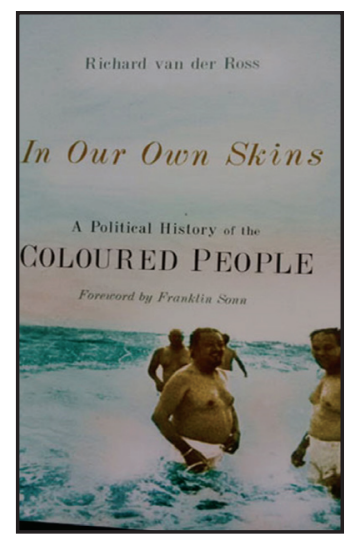

Titel: In our own skins:

Sub-titel: A Political History of the Coloured People

Outeur: Richard van der Ross

Uitgewer: Jonathan Ball Uitgewers, Johannesburg \& Kaapstad

ISBN 13: 9781868426676

Jaar: 2015

Bladsye: 224

R194.00 by Exclusive Books

\title{
Bruinmense se stryd teen apartheid gedokumenteer
}

Ek was 'n student aan die UWK toe prof. Van der Ross die rektor was. Op 93-jarige ouderdom is hy steeds 'n merkwaardige man. Die laaste keer dat ek hom gesien het, was September 2012 toe hy Adam Small se terugkeer na die openbare lewe tydens 'n viering op Wellington bygewoon het. En ten spyte van sy ouderdom, het hy my herken. Bygevoeg, in 1977 was daar maar min van ons op die UWK. Ek lees ' $n$ joernalis skryf dié oud-rektor van die Universiteit van Wes-Kaapland is op 93 nog vol grappe, maar ook ietwat sinies: "Dis lekker om 'n bruin man te wees, dis lekker om te jol en dis lekker om te sê: 'Moenie 'n bleddie fool wies nie'," het hy geskerts.

Van der Ross het egter bygevoeg: "Bruinmense behoort aan 'n gemeenskap met talle probleme. Ons gemeenskappe is deurmekaar geskeur deur vele sosiale probleme. Sommige van ons mense druk liewers mekaar af, pleks daarvan om sy medemens te help. Om in Suid-Afrika te woon, is baie lekker, maar soms vind Bruinmense dit moeilik om hier te wees, want ons trek nie dieselfde voordeel uit die land as ander rasgroepe nie."

Hierdie as agtergrond tot die volgende boekbespreking. Ek verlaat my aanvanklik op die eerste twee hoofstukke in die boek: die eerste deur Van der Ross se tydgenoot, Franklin Sonn, voormalige ambassadeur en rektor van die Skiereilandse Technikon, vandag die Kaapse Skiereilandse Universiteit van Tegnologie; die tweede deur van der Ross self.

Maar eers moet ek iets sê oor die gebruik van die terme "Coloured", "Kleurling" en "bruin". Eerstens: die Coloured mense op hul eie, is nie 'n nasie of 'n ras nie(1). Trouens, die skrywer verwys self daarna as hy sê: " Daar sal diegene wees wat die boek sal kritiseer, wat sal sê die boek moes in die eerste instansie nooit geskryf gewees het nie, want daar is nie iets soos "Coloured people" nie (8).

Die leser sal opmerk dat ek "Coloured" in aanhalings/kursief gebruik. Ek gebruik ook nie die woord "Kleurling" nie. Want vreemd soos wat dit vir sommige lesers sal klink, is Coloured en Kleurling nie sinonieme nie, die een is nie 'n vertaling van die ander nie. Hierdie groep mense is self meer gemaklik met die Engelse woord Coloured as met die Afrikaanse woord "Kleurling". Laasgenoemde is polities baie swaar gelaai en die meeste Bruinmense met wie ek interaksie het, vermy, ja verafsku selfs die woord. Dis vir ons die "K"-woord wat net so seermaak as die K-woord wat na swart mense verwys. Die woord hou die betekenis in dat enigeen wat nêrens inpas nie, word hieronder gegooi. Dis byna soos die drogwoord "Other" wat deesdae op al wat 'n vorm is, verskyn wat deur staatsamptenare ingevul moet word. Dit is kwetsend en moet liefs vermy word. Daarom 
verkies baie mense - ook hierdie skrywer - die verwysing Bruinmense terwyl ander ook die woord Coloureds gebruik, selfs in Afrikaans.

Die boek is in Engels geskryf, daarom gebruik Van der Ross strykdeur die woord Coloured maar ek vertaal dit met Bruinmense, let wel met 'n hoofletter soos ook Coloured. Ek gebruik dus nie die woord bruin as 'n adjektief nie, want nie alle Bruinmense is bruin van kleur nie, sommige is swart, ander wit, ander iets tussenin. Bruinmense verwys na almal wat hulself tuisvoel by die groep mense wat in Engels as die Coloureds bekend staan.

Die ander saak wat in die reine gestel moet word, en wat hier breedvoerig deur Van der Ross bespreek word, is die neiging om in sommige kringe na Bruinmense as Khoisan, Khoi of San te verwys. Niks kan verder van die waarheid verwyder wees nie, sê Van der Ross.

Die San (deur die Hollanders Bosjemannen gedoop) was jagters en het geleef van hul prooi, vis uit die see, bessies, wortels en vrugte wat hulle bymekaar kon maak. Vir water en kos moes hierdie nomadiese volk van plek tot plek beweeg (12). Die Khoi, daarenteen, was meer standvastig, het hutte gebou en vee aangehou. Hulle het in groter groepe (stamme) gewoon en het dikwels handel gedryf met die Setlaars as laasgenoemde kos, veral vleis, in die hande wou kry (13). Hulle was in 'n sekere mate ook nomadies (agter kos vir hul vee aan) maar minder so as die San. Beide groepe sou later Eerste-nasie-status van Suider-Afrika kry (14).

Om dus Bruinmense gelyk te stel aan die Khoi en die San is nie net feitelik verkeerd nie, dit getuig van 'n ontkenning van Bruinmense se ware menswees en selfs 'n wegkyk van die feit dat Bruinmense in die eerste plek 'n produk tussen hoofsaaklik manlike Europeërs en vroulike Khoi- en slawevroue was. Van der Ross skryf dat in die tyd van Jan van Riebeeck daar 100 Hollandse mans maar slegs 10 vroue aan die Kaap was. Heelwat Europeërs het met Khoi-vroue of slavinne (uit Maleisië en Indonesië) gemeng en getrou.

So byvoorbeeld was daar Autshumato, oftewel Harry die strandloper, wie se dogter, Krotoa ook bekend as Eva - aan die hof van Jan van Riebeeck gewerk het as 'n tolk. Sy kon danksy haar pa, wat reeds per skip na Holland gereis het, beperkte Hollands praat. Sy trou later met Pieter van Meerhof. Die bekende navorser HF Heese bevind dat tussen 1652 en 1795 daar 1273 sulke huwelike was (29). So wie is die Coloured mense? Daar is bewyse van die San en die Khoi in ons (22), maar daar is ook bewyse van Hollandse, Duitse, Britse, Ierse, Franse, Spaanse, Skandinawiese, Arabiese, en Xhosa-bloed in Bruinmense.

Om dus 'n boek oor die Coloureds en hul unieke geskiedenis te probeer skryf, is en was nog altyd ' $n$ baie omstrede onderwerp. Die groep het nog altyd weerstand gebied teen rassisme en enige poging deur kolonialiste en post-koloniale regerings om aan hulle ' $n$ bepaalde soort politieke status te gee, is deur die groep verwerp. Tog is Van der Ross geheel en al gemaklik in sy eie vel, soos die titel van die boek suggereer. Hy is 'n goeie voorbeeld van 'n nie-rassis in sy daaglikse omgang met mense, en tog identifiseer hy baie sterk met die Coloureds en verwys dwarsdeur die boek na die Bruinmense in die meervoudige eerstepersoon as "ons" mense se gewoontes, kultuur, geskiedenis en lewensbeskouing.

Van groot waarde is die samesprekings wat Van der Ross gehad het met Nelson Mandela, op laasgenoemde se aandrang, as verteenwoordiger van die Coloured Convention Planning Committee in 1962 oor die ANC se beplande opstand teen apartheid en die rol wat Mandela vir Bruinmense in hierdie aksie gesien het (2).

Baie interessant vir hierdie skrywer, is die gedeelte oor dr. Abdullah Abdurahman. Teen die einde van 1800 het die Bruinmense stewig gegroei, nie net in getalle nie, maar ook in terme van hul politieke bewussyn. Die Anglo-Boere-oorlog het almal in Suid-Afrika beïnvloed, ook die Bruinmense, en in 1902 is ' $n$ politieke vergadering in Kaapstad gehou om eenheid onder Bruinmense te bewerkstellig. Dit het aanleiding gegee tot die ontstaan van die African Political Organisation (APO). Die party het 
egter leierskap gekort, 'n kenmerk waaroor dr. Abdurahman beskik het (39). Hy was, soos hierdie skrywer, 'n Wellingtonner van geboorte en die seun van die bevryde slaaf Abdul Abdurahman. Hy was ' $n$ leerder aan dieselfde Sendingskool as ek en kwalifiseer as 'n mediese dokter. Later verlaat hy Wellington en vestig hom in Kaapstad waar hy as pionier-politikus hom by die APO aansluit. Oor sy Ierse vrou, Miss Ellie, en hul dokter-kinders moet die leser maar self gaan lees.

Ook interessant is die sentrale rol wat onderwyser-organisasies en sportliggame gespeel het in die struggle. Teen 1910 was daar reeds twee onderwyser-unies in die Kaap. Die een was die SuidAfrikaanse Onderwysersunie (SAOU), maar dit was veral die Teachers League of South Africa (TLSA) waarvan Van der Ross 'n aktiewe lid was, wat groot aanhang geniet het onder Bruinmense (103). Dit was weereens Dr Abdurahman wat met twee prominente bruin onderwysers onderhandel het om die TSLA te vorm: Harold Cressey en HJ Gordon. Eersgenoemde was die eerste Bruinmens wat 'n BA-graad verwerf het en vandag heet twee prominente skole in die Kaap na Harold Cressey en HJ Gordon. Later sou die liggaam ontbind en oorsprong gee aan die Kaaplandse Professionele Onderwysvereniging (KPO) waarvan Franklin Sonn en na hom Randall van den Heever en Archie Vergotine die presidente was. Hierdie skrywer was sedert sy eerste dag as onderwyser lid van die KPO wat baie voordele soos medies en regsverteenwoordiging aan sy lede gebied het. Teen 1940 was die APO en die TSLA die mees gesogte organisasies waaraan Bruinmense behoort het (103).

Sonn beskryf met nostalgie sy eerste kennismaking met Van der Ross, toe hy, as 'n jong man van skaars twintig, met durf sy onderwyser-kollegas aangevuur het tydens 'n konferensie in die Maitland Stadsaal in Kaapstad. Hierdie pogings sou daartoe lei dat die TLSA en die KPO die Vryheidsmanifes aanvaar het as riglyn vir hul aksies. Vir baie Bruinmense het hierdie organisasies dus hulle stem teen apartheid geword.

Van der Ross wei ook uit oor die rol wat sekere kerke in die stryd teen apartheid gespeel het - veral die eertydse NG Sendingkerk - vandag die Verenigde Gereformeerde Kerk (VGK) waarvan hierdie skrywer terloops ' $n$ lid is. Dit was veral onder die leiding van Dr Allan Boesak dat die kerk openlik en aggressief 'n stem vir Bruinmense geword het teen apartheid (2). Van der Ross beskryf hoe die NP die waardevolle "bruin stem" verloor het (45) en ten spyte van die geveg wat Bruinmense van stapel gestuur het, en die petisie wat oorhandig is (o.a. deur 'n baie jong Van der Ross) kon dr. DF Malan hom nie daaraan steur nie. Bruinmense het gevolglik hul parlementêre stem wat hulle vir meer as 150 jaar gehou het, verloor (129).

Dis logies dat Van der Ross as synde 'n onderwysman in murg en been, spesiale aandag sou gee aan bruin onderwys. So lees ons dat in 1915 was daar slegs 19 bruin leerders in st.7 of hoër (83), en dat Dr Abdurahman die regering gekritiseer het omdat bruin onderwys skandalig onderbefonds was (103). Daar was in 1915 gemiddeld 43 bruin leerders in 'n klas vergeleke met wittes (22) en swartes (33).

Ander minder bekende maar interessante aspekte wat die boek uitlig, is dat die Bruinmense hul eie Afrikaanse Nasionale Bond gestig het in 1924 (41) met dr. Abdurahman se broer dr. Ismael Abdurahman aan die spits (42); dat die regering in 1920 besluit het om nie die politieke aktivis, Clemens Kadalie (vader van Rhoda) te deporteer nie en dat die Klopse Karnaval van 1921 in die destydse Groenpunt Stadion die grootste en bes georganiseerde karnaval nog was (93). Voorvalle van slawerny het nog in 1923 voorgekom (103) en heelwat Bruinmense het saam met die boere getrek toe die verhouding tussen wit en bruin nog baie goed was (105). Die beskrywing van eerwaarde Allan Hendrickse, intyds die leier van die bruin Arbeidersparty, se stryd om strand-apartheid afgeskaf te kry (soos die foto op die voorblad uitbeeld) bied ewe-eens boeiende leesstof.

Die leser sal sommige gedeeltes van die boek vermoeiend vind, veral omdat Van der Ross dikwels van sitate uit die APO-koerant gebruik maak. Dit was 'n struggle koerant wat nie so algemeen bekend is nie. Hy maak egter geen verskoning daarvoor nie, omdat geen ander koerant hul storie 
wou vertel nie, en daar dus geen ander bronne beskikbaar was nie. Die boek handel oor die geskiedenis van 'n klein deel van Suid-Afrika se bevolking. Dit gaan egter oor meer as net Bruinmense, maar ook oor alle Suid-Afrikaners, juis omdat Bruinmense onlosmaaklik deel is van almal in SA. Dit vertel die verhaal van drie en 'n half eeue se swaarkry, en die pyn van verwerping en uitsluiting. Dit, maar ook die stappe wat Bruinmense gedoen het om hulself op te hef en die gepaardgaande suksesse van hoop, uitnemendheid en inspirasie,vorm die ruggraat van hierdie boek.

In 'n onderhoud met 'n koerant het Van der Ross genoem daar is nog hoop vir Bruinmense. "Kyk na die burgemeester van Kaapstad. Sy is bruin. Kyk na die nalatenskap van prof. Jakes Gerwel. Hy was 'n wonderlike man. Ons het nog baie ander goeie leiers", het hy gesê met die bekendstelling van die boek, wat lesers met 'n belangstelling in Geskiedenis moet aanskaf.

Danksy leiers soos Van der Ross asook proff. Gerwel, Small en O'Connell is die studente van die UWK beklee met waardes en vaardighede wat internasionale aansien aan die UWK verleen het. Die universiteit is onlangs aangewys as die 5de beste universiteit uit 27 in SA. Dis 'n reuse prestasie vir 'n kampus wat eens as Bush-kollege bekend gestaan het.Vandag is prof. Van der Ross'n ereburger van Kaapstad. Is dit te veel gevra om Modderdamweg te vernoem na hierdie merkwaardige man? Of dat die Akademie kom vereer?

\section{Michael le Cordeur}

\section{Universiteit Stellenbosch}

E-pos: mlecorde@sun.ac.za 